\title{
Ethnic and genetic factors associated with hostility of adolescents and young adults
}

\author{
Anna Kruchkova ${ }^{1, *}$, Ekaterina Denisova ${ }^{1}$, Anastasia Kolenova ${ }^{1}$ and Anna Kukuliar $^{1}$ \\ ${ }^{1}$ Don State Technical University, Rostov on Don 344000, Russia
}

\begin{abstract}
The Last decades have witnessed elevated tension and conflicts in young people's environment. There has been an increase in crime, terrorism, suicides, addictions, and other behavioral deviations among the young. Up to the 21 st century, hostility was equated with aggression in its broad, non-differentiated sense. Today hostility is considered to be an inflexible and complex personality trait. Recent studies show that several genes can be viewed as genetic predictors of aggressiveness and hostility (Rodríguez-Ramos Á., Et al., 2019; Tkachenko O.N., 2016). The paper investigates the relationship between genotype and ethnicity as predisposing factors in manifesting hostile behavior. The study involved 320 participants - adolescents and young men of different ethnicity (Russians, Armenians, Dagestanis, Kabardians), aged from 12 to 19. Research methods: BussDurkee Hostility inventory (in the adaptation of Osnitsky A.K., 1998); isolation genomic DNA from buccal epithelial cells. Genotypes and alleles of the monoamine oxidase enzyme (MAOA) gene were considered as a candidate gene. Statistical analysis and data processing were performed using the PSPP 0.85 . It was established that the low-active variant of the MAOA monoamine oxidase A gene (LPR) plays a significant role in determining the risk of hostile behavior. As far as the ethnic factor is concerned, low-level MAOA variants have significant differences in the populations of Russians compared with Dagestanis, or Kabardians. The results received contribute to understanding the relationships between genetics and behavior. It will help develop effective methods for the prevention of aggressive and hostile behavioral patterns.
\end{abstract}

\section{Introduction}

The problem of studying hostile behavior in the youth environment has recently acquired particular relevance due to increased tensions, hostility, and conflict behavior of adolescents and young adults in modern society. Up to the 21 st century, hostility was equated with aggression in its broad, non-differentiated sense. Discussions regarding aggression have dominated research in many years and only in recent decades the academic community extensively explores the problem of hostility (Alfimova M.V., Golimbet V.E., Yegorova M.S., 2009; Enikolopov S.N., Sadovskaya A.V., 2000; Ermakov P.N., 2014; Ermakov P.N., Abakumova I. V., 2011).

\footnotetext{
*Corresponding author: Kolenova.nastya@ya.ru
} 
Today, hostility is considered to be a stable and complex personality trait, implying the devaluation of the motives and personality traits of other people, a sense of being in opposition to others, and wishing them harm (actively or passively) (Alfimova M.V. Trubnikov V.I., 2000; Barefoot J.C., 1992; Birger M., Swartz M., Cohen D. et al., 2003). Some authors have also posited the division into manifested and experienced hostility (Berkovits L., 2001; Baron R., Richardson D., 1994; Enikolopov S.N., Sadovskaya A.V., 2000; Petrenko R.A., 2010).

Prior research generally suggests that there are three main areas of applied studies of hostility in modern science: the study of behavioral manifestations of hostility, the study of the effect of hostility on physical health (psychological factors of asthma, cardiovascular pathology, etc.), the study of hostility accompanying various mental disorders (Byrd, A. L., Manuck, S. B, 2014; Nilsson, K. W. et al., 2018; Pełka-Wysiecka, J. et al., 2012; Tkachenko O.N., 2016). And since the understanding of the term varies in these areas, in the framework of this study by hostility we will mean a negative, oppositional attitude to the world (primarily to people) of a predominantly cognitive nature, implying the existence of negative attitudes, emotions and behavioral patterns in the form of aggression, negativism, detachment, autization, etc.

The search for the biological basis of hostility is one of the most interesting areas of modern research on this subject. For example, R. Williams and his colleagues discover and describe the connection of chronic hostility with increased content of testosterone in the blood (Egorova M.S., 1995; Enikolopov S.N., Sadovskaya A.V., 2000; Malykh S.B., Yegorova M.S., Meshkova T.A., 1998). K. Fall and colleagues note that different forms of schizophrenia and hostility indicators corresponding to different concentrations of serotonin metabolites in the cerebrospinal fluid (Egorova M.S., 1995; Ravich-Shcherbo I.V., Maryutina T.M., Grigorenko E.L., 1999). In postpartum depression studies has been found that high levels of prolactin in the blood of women who have recently given birth correspond to an increase in hostility and anger (Egorova M.S., Chertkova Yu.D., 2011; Eisenberger N., et al., 2007; Vorobyeva E.V., 2006).

Much is known about the MAOA gene which is located on the $\mathrm{X}$ chromosome. Gene molecules are distributed around the junction points of the neurons where occurs the transmission of the impulses from one neuron to another. At the same time, some neurotransmitters remain in the space between the cells. If they are quickly inhibited by monoamine oxidase, the arousal quickly fades away and the person feels calm. When the monoamine oxidase is destroyed the excitement is elongated and the person is greatly irritated (Byrd, A. L., Manuck, S. B, 2014; Rodríguez-Ramos Á., et al., 2019; Tkachenko O.N., 2016).

The polymorphism of the number of tandems repeats MAOA represented by alleles carrying $2,3,3.5,4$, and 5 repeats of a certain segment of DNA in the regulatory region of this gene. The most common alleles are 3 and 4. This polymorphism affects gene transcription. Previous studies have promoted alleles 3.5 and 4 as associated with high activity of the gene and enzyme, the rest - with low activity, and allele 3 leads to a fivefold decrease in transcriptional activity compared to allele 4 (Alfimova M.V. Trubnikov V.I., 2000).

Prior research generally confirms that the carriers of the low-active MAOA allele have distinct asocial features, they are highly aggressive and impulsive, anxious, prone to guilt, tend to overestimate the dangers they face, which differs from those with a highly active allele (Reti I.M., et al. 2011). However, despite the increased interest of the scientific community on the issue of human hostility, there is still a significant shortage of works devoted to the connection of hereditary factors with this psychological characteristic.

Consequently, we are interested in the association of the polymorphisms of the MAOA gene as a possible indicator of the genetic predisposition to hostile behavior in adolescents 
and young men of different ethnicity. The objectives of the research include determining the level of hostility among adolescents and young people of different ethnic backgrounds; conducting a molecular genetic study; assessing the level of hostility based on genetic factors.

\section{Materials and methods}

Psychological testing. To determine the level of hostility we used Buss-Durkee Hostility inventory (in the adaptation of Osnitsky A.K., 1998). This questionnaire is one of the most widely accepted reliable methods for studying aggression. The authors identify seven forms of aggressive and hostile reaction of a person: physical, indirect, verbal aggression, tendency to irritation, negativism, resentment, suspicion. The sum of the results on the scales "irritation", "physical aggression", "indirect aggression", and "verbal aggression" form the index of aggressive reactions (IAR). IAR can have a value from 0 to 43 (the sum of 1,2,3 and 7 scales).

Molecular genetics. Genotypes and alleles of the monoamine oxidase enzyme (MAOA) gene were considered as a candidate gene. To determine polymorphic variants of the MAOA gene, we used genomic DNA isolation from buccal epithelial cells.

Molecular genetic research was performed on the equipment of the center of collective use of the Southern Federal University "High Technologies".

To determine the significance of the results, we used statistical processing using the PSPP 0.8.5. The significance of the differences was taken at $\mathrm{p}<0.05$.

The sample. The study involved 320 individuals - adolescents and young men of different ethnicity (Russians, Armenians, Dagestanis, Kabardians), aged 12 to 19 years.

\section{Results}

Table 1 shows the results of a molecular genetic analysis of the distribution of polymorphic MAOA variants in the sample.

Table 1. The distribution rate of the MAOA gene alleles (in percent).

\begin{tabular}{|c|c|c|c|}
\hline \multicolumn{2}{|r|}{ Variables } & $\begin{array}{c}\text { Sample size } \\
\text { (suboroups } \mathbf{N} \text { ) }\end{array}$ & $\%$ \\
\hline \multirow{3}{*}{ 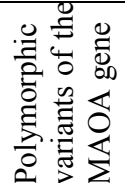 } & $\begin{array}{l}\text { Carriers of low-active gene } \\
\text { (allele 3) }\end{array}$ & 61 & 19 \\
\hline & $\begin{array}{l}\text { Carriers of highly-active gene } \\
\text { (allele } 3.5,4)\end{array}$ & 208 & 65 \\
\hline & Carriers of both alleles & 51 & 16 \\
\hline
\end{tabular}

The table 1 shows that the sample is dominated by carriers of highly-active gene (allele $3.5,4)$. Carriers of the low-active variant of the MAOA gene are $19 \%$ of the sample, and carriers of both alleles are $16 \%$. Obtained data correspond to classic statistical data on the distribution of these polymorphisms in populations (Sabol S.Z., Hu S., Hamer D. A, 1998).

We also analyzed the frequency of occurrence of genetic polymorphisms in different ethnic groups. The results relating to it are presented in Table 2.

Table 2. frequency of occurrence of genetic polymorphisms of the MAOA gene in different ethnic groups.

\begin{tabular}{|l|c|c|c|c|}
\hline \multicolumn{2}{|c|}{} & allele 3 & allele 3.5, 4 & both alleles \\
\hline \multirow{2}{*}{ Russians } & $\mathrm{N}$ & 9 & 62 & 12 \\
\cline { 2 - 5 } & $\%$ & 10.84 & 74.70 & 14.46 \\
\hline \multirow{2}{*}{ Kabardians } & $\mathrm{N}$ & 23 & 34 & 21 \\
\cline { 2 - 5 } & $\%$ & 29.49 & 43.59 & 26.92 \\
\hline
\end{tabular}




\begin{tabular}{|l|c|c|c|c|}
\hline \multirow{2}{*}{ Dagestanis } & $\mathrm{N}$ & 25 & 33 & 19 \\
\cline { 2 - 5 } & $\%$ & 32.47 & 42.86 & 24.68 \\
\hline \multirow{2}{*}{ Armenians } & $\mathrm{N}$ & 14 & 50 & 18 \\
\cline { 2 - 5 } & $\%$ & 9.76 & 74.39 & 15.85 \\
\hline
\end{tabular}

The data allow us to conclude that between groups of Russians and Armenians, there is a similarity in the percentage distribution of polymorphisms, as well as in groups of Kabardians and Dagestanis. In the Russian and Armenian populations the low-active version of the gene corresponds to $10.84 \%$ and $9.76 \%$, highly active to $74.70 \%$ and $74.39 \%$, the presence of both alleles occurs in $14.46 \%$ and $15.85 \%$ of sample. In Dagestanis and Kabardin populations, the distribution of the low-active gene variant is $32.47 \%$ and $29.49 \%$, highly active in $42.86 \%$ and $43.59 \%$, and both alleles simultaneously in $24.68 \%$ and $26.92 \%$ of subjects.

A comparative analysis using the chi-square test showed that the distribution of the lowactive variant of the MAOA gene has statistically significant differences in the populations of Russians compared with Dagestanis, or Kabardians ( $p<0.006)$.

The results relating to the tendency for hostility, obtained using the Buss-Durkee Hostility inventory, in carriers of various alleles of the MAOA gene are presented in Table 3.

Table 3. Indicators of hostility index obtained using the Buss-Durkee Hostility inventory among carriers of various polymorphisms of the MAOA gene.

\begin{tabular}{|c|c|c|c|c|c|}
\hline \multicolumn{3}{|c|}{ Factors } & $\begin{array}{l}\text { High hostility } \\
\text { levels }\end{array}$ & $\begin{array}{c}\text { Average } \\
\text { hostility levels }\end{array}$ & $\begin{array}{c}\text { Low } \\
\text { hostility }\end{array}$ \\
\hline \multirow{6}{*}{ 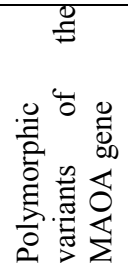 } & \multirow{2}{*}{$\begin{array}{l}\text { Carriers of low-active } \\
\text { gene (allele 3) }\end{array}$} & $\mathrm{N}$ & 59 & 2 & 0 \\
\hline & & $\%$ & 97 & 3 & 0 \\
\hline & \multirow{2}{*}{$\begin{array}{l}\text { Carriers of highly- } \\
\text { active gene (allele } \\
3.5,4)\end{array}$} & $\mathrm{N}$ & 55 & 146 & 7 \\
\hline & & $\%$ & 26.5 & 70.2 & 3.3 \\
\hline & \multirow{2}{*}{$\begin{array}{l}\text { Carriers of both } \\
\text { alleles }\end{array}$} & $\mathrm{N}$ & 28 & 21 & 2 \\
\hline & & $\%$ & 55 & 41 & 4 \\
\hline
\end{tabular}

Analysis of the data in the tables shows that a high level of hostility is observed in $97 \%$ of young people with allele 3 (low enzymatic activity). The findings suggest that subjects with a low-active (allele 3) gene variant (MAOA) have a high index of hostility almost universally.

To verify this observation, we used single-factor analysis of variance, where genetic parameters acted as an independent variable, and dependent ones - various forms of hostility. Univariate ANOVA indicate the presence of a significant effect $(F=24,30 ; p<0,05)$ between the propensity to hostile behavior with low activity for this gene enzyme A MAOA (LPR).

Based on the research data, we have shown that the low-level variant of the enzyme monoamine oxidase a MAOA (LPR) plays an important role in determining the propensity for aggressive and hostile behavior. We were also have been able to find a link in the distribution of polymorphic variants of MAOA gene ethnicity.

\section{Discussions}

The obtained data on the association of the MAOA gene with hostility are consistent with the ideas about the contribution of the MAOA to the formation of an asocial personality (Alfimova M.V., Trubnikov V.I., 2000). According to the results of the study, the lowactivity variant of the MAOA monoamine oxidase A enzyme (LPR) determines the risk of the presence of hostile behavior. The implementation of such behavioral attitudes corresponds to the individual's emotional response patterns. The participation of MAOA in the exchange of serotonin, which is usually associated with impulsivity, aggression, anxiety 
and interpersonal sensitivity, can explain this behavior (Alfimova M.V., Trubnikov V.I., 2000; Coccaro E.F., Bergerman C., Kavoussi R.J., Seroczynski A., 1997; Vorobyeva E.V., 2006). Our findings do not contradict the results of recent studies, which show that the presence of low-activity MAOA alleles correlates with the "interpersonal hypersensitivity" trait, reflecting self-doubt, feelings of a hostile environment around yourself, etc. (Byrd, A.L., \& Manuck, S.B., 2014; Kim-Cohen J., et al. 2006). Moreover, the latter, together with the hyperactivation of the dorsal parts of the anterior cingulate cortex in a situation that simulates social rejection, mediates the influence of the MAOA gene on aggressiveness (Kim-Cohen J., et al. 2006; Kovsh, E., Vorob'eva, E., Ermakov, P., 2014; Reti I.M., et al. 2011).

\section{Conclusions}

This study was designed to investigate the biological component and its role in the formation of hostile behavior by young people of different ethnic backgrounds. The research conducted in the adolescent and young age groups shows that:

1) Ethnicity affects the polymorphic variants of the MAOA gene.

2) The distribution of low-level MAOA variants in the populations of Russians and Dagestanis, as well as Kabardians, has statistically significant differences. One third of the population of Kabardians and Dagestanis have this polymorphism, in contrast to Russians and Armenians, where it is only in $8-9 \%$.

3) There is a significant effect between the propensity to hostile behavior with low activity MAOA enzyme gene.

The applied value of the research is that its results can be used in the development of psycho-preventive measures for its correction.

\section{Acknowledgements}

This research was funded by the Russian Foundation for Basic Research (RFBR), project № 18-29-22004.

\section{References}

1. M.V. Alfimova, V.E. Golimbet, M.S. Yegorova, Psychology. Journal of the Higher School of Economics 6(4), 24-41 (2009)

2. J.C. Barefoot, Developments in the measurement of hostility. Hostility, coping, \& health (1992) https://doi.org/10.1037/10105-001

3. R.A. Baron, D.R. Richardson, Perspectives in social psychology. Human aggression (1994)

4. L. Berkovits, Aggression: causes, consequences and control (Sant-Petersburg, Russia, 2001)

5. M. Birger, M. Swartz, D. Cohen, Y. Alesh, C. Grishpan, M. Kotelr, The Israel Medical Association journal: IMAJ 5(9), 653-8 (2003)

6. A.L. Byrd, S.B. Manuck, Biological Psychiatry 75(1), 9-17 (2014) https://doi.org/10.1016/j.biopsych.2013.05.004

7. E.F. Coccaro, C. Bergerman, R.J. Kavoussi, A. Seroczynski, Biological Psychiatry 1.41(3), 273-84 (1997) https://doi.org/10.1016/s0006-3223(96)00257-0

8. M.S. Egorova, Genetics of behavior: psychological aspect (Moscow, Russia, 1995) 
9. N. Eisenberger, B.M. Way, S.E. Taylor, et al, Biological Psychiatry 61(9), 1100-1108 (2007) https://doi.org/10.1016/j.biopsych.2006.08.007

10. S.N. Enikolopov, A.V. Sadovskaya, Korsakov Journal of Neurology and Psychiatry 7, 59-64 (2000)

11. P.N. Ermakov, International Journal of Psychophysiology 2, 143 (2014)

12. P.N. Ermakov, I.V. Abakumova, Russian Psychological Journal 9(4), 11-15 (2012)

13. J. Kim-Cohen, A. Caspi, A. Taylor, et al, Molecular Psychiatry 11(10), 903-13 (2006) https://doi.org/10.1038/sj.mp.4001851

14. S.B. Malykh, M.S. Yegorova, T.A. Meshkova, Fundamentals of psychogenetics (Moscow, Russia, 1998)

15. K.W. Nilsson, C. Åslund, E. Comasco, L. Oreland, Journal of Neural Transmission 125(11), 1601-1626 (2018) https://doi.org/10.1007/s00702-018-1892-2

16. J. Pełka-Wysiecka, J. Ziętek, A. Grzywacz, et al, Progress in NeuroPsychopharmacology and Biological Psychiatry 39(1), 40-46 (2012) https://doi.org/10.1016/j.pnpbp.2012.04

17. R.A. Petrenko, Social and Environmental Technologies 5, 94-100 (2010)

18. I.V. Ravich-Shcherbo, T.M. Maryutina, E.L. Grigorenko, Psychogenetics (Moscow, 1999)

19. I.M. Reti, J.Z. Xu, J. Yanofski, et al, Comprehensive psychiatry 52(2), 188-194 (2011) https://doi.org/10.1016/j.comppsych.2010.05.005

20. Á. Rodríguez-Ramos, J.A. Moriana, F. García-Torres, M. Ruiz-Rubio, Brain and behavior 9(9), e01376 (2019) https://doi.org/10.1002/brb3.1376

21. S. Sabol, S. Hu, D. Hamer, Human Genetics 103, 273-279 (1998) https://doi.org/10.1007/s004390050816

22. O.N. Tkachenko, Social and Environmental Technologies 3, 68-86 (2016)

23. E.V. Vorobyeva, Intellect and achievement motivation: psychophysiological and psychogenetic predictors 1, 123-125 (2006) 